\title{
Imported dengue virus serotype 1 from Madeira to Finland 2012
}

E Huhtamo (eili.huhtamo@helsinki.fi) ${ }^{1}$, E M Korhonen ${ }^{1}, 0$ Vapalahti ${ }^{1,2,3}$

1. Department of Virology, Haartman Institute, Faculty of Medicine, University of Helsinki, Helsinki, Finland

2. Department of Virology and Immunology, Helsinki University Central Hospital Laboratory (HUSLAB), Helsinki, Finland

3. Department of Veterinary Biosciences, Faculty of Veterinary Medicine, University of Helsinki, Helsinki, Finland

Citation style for this article:

Huhtamo E, Korhonen EM, Vapalahti O. Imported dengue virus serotype 1 from Madeira to Finland 2012. Euro Surveill. 2013;18(8):pii=20405. Available online: http://www.eurosurveillance.org/ViewArticle.aspx?Articleld=20405

Article submitted on 06 February 2013 / published on 21 February 2013

Imported dengue cases originating from the Madeiran outbreak are increasingly reported. In 2012 five Finnish travellers returning from Madeira were diagnosed with dengue fever. Viral sequence data was obtained from two patients. The partial C-preM sequences (399 and 396 bp respectively) were found similar to that of an autochthonous case from Madeira. The partial E-gene sequence (933 bp) which was identical among the two patients grouped phylogenetically with South American strains of dengue virus serotype 1.

Between August and December 2012, the hospital district of Helsinki and Uusimaa laboratory (HUSLAB) which solely performs dengue diagnostics in Finland, received samples from 16 patients with clinically suspected dengue fever and who had visited the Autonomous Region of Madeira, Portugal, where an outbreak of dengue fever is taking place since the beginning of October $2012[1,2]$.

\section{Confirmation of dengue virus infection}

The serum samples of the patients were analysed by dengue non-structural protein (NS)1 antigen (Ag) strip test (BioRad), IgM-enzyme immunoassay (EIA) (Focus Technologies) and an in-house IgG immunofluorescence assay (IFA) using dengue virus (DENV)-3 infected Vero E6 cells as antigens. The dengue diagnosis was confirmed in five patients by serological tests. Three of five serologically-confirmed patients were also positive for $\mathrm{NS}_{1} \mathrm{Ag}$.

The earliest available samples of the five serologicallyconfirmed dengue patients were studied by reverse transcription-polymerase chain reaction (RT-PCR) to obtain information of the infective virus strain. RNA was extracted from serum samples using QIAamp viral RNA mini kit (Qiagen) according to manufacturer's instructions. The RNA was used as a template in dengue typing RT-PCR [3] and in an RT-PCR amplifying a partial sequence of the envelope gene (E-gene) [4]. RT-PCR products were obtained from two patients, for which the typing RT-PCR product size corresponded to DENV serotype 1 (DENV-1) [3].
The obtained RT-PCR products were purified enzymatically using ExoSAP-IT (USB laboratories) and directly sequenced (in case of E-gene, using DENV-1 E-gene specific primers). Primer sequences are available from the authors upon request). The obtained sequences of the E-gene ( $933 \mathrm{bp}$ ) from the two patients were identical to one another and the sequence information was deposited in GenBank under accession number:

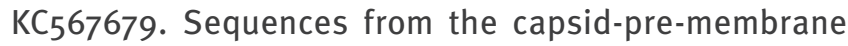
(C-preM) region [3] derived from the first patient (399 bp, GenBank accession number: KC616348) and the second patient (396 bp, GenBank accession number: KC616349) differed from each other by one nucleotide.

The sequences from the patients were compared to available DENV sequences in GenBank database and the basic local alignment search tool (BLAST) results confirmed that the infective virus was DENV-1. This finding was in line with the typing RT-PCR results and with previous reports $[1,5,6]$.

The two RT-PCR positive patients had returned from Madeira in November 2012. The first patient was a female in her 50s, who was IgG negative but NS1 Ag and IgM positive in the first sample (used for RT-PCR), and IgG seroconverted after one week with an IgG titre of 80 (IFA). The second patient was a man in his 6os, whose first available sample was positive for IgM and $\mathrm{NS}_{1} \mathrm{Ag}$, and borderline positive in the IgG test, but for whom a sample collected five days later had an IgG titre of 1,280 (IFA). The symptoms of both patients could be regarded as typical for dengue fever including fever $\left(\geq 38^{\circ} \mathrm{C}\right)$, headache, muscle pains, rash and gastrointestinal symptoms.

\section{Phylogenetic analysis of the viral sequence derived from the patients}

All of the four known serotypes of DENV are further genetically categorised into several distinct genotypes. Two different ways of categorising DENV-1 strains have been used: into three [7-9] or into five different genotypes [10-12]. The DENV-1 viruses include a sylvatic strain originating from Malaysia (designated as sylvatic genotype or genotype III). In the five genotype 
classification, some strains originating from Thailand in the 1950 s and 1960 s are designated as genotype II.

All the rest of the epidemic strains can be divided into three main groups corresponding to a three genotype classification. These groups include: (i) mainly Asian strains and some east African strains designated as genotype I (or Asian I genotype in the five genotype classification), (ii) strains originating mainly from the west Pacific islands and Australia designated as genotype II (or South Pacific genotype IV in the five genotype classification), and (iii) strains originating from Africa, some Asian strains and all strains originating from the Americas designated as genotype III (or American/African genotype V in the five genotype classification). To identify dengue virus strain(s) responsible for a given outbreak, characterisation of the infecting virus by sero- and genotyping is needed. Although dengue viruses currently have a global circulation, their genetic characterisation likely provides clues of their origins.

The E-gene sequence derived from the patients was aligned with sequences sharing highest nucleotide homologies in GenBank and with a global collection of representatives of different recent epidemic DENV-1 genotypes using multiple sequence comparison by log expectation (MUSCLE) (www.ebi.ac.uk/Tools/msa/ muscle/) and a neighbour-joining phylogenetic tree was estimated with the maximum composite likelihood method using the programme MEGA (www.megasoftware.net/) (Figure).

The results suggested that the Madeiran strain represented the American/African genotype (designated as genotype III or V). In the phylogenetic tree, the Madeiran strain was clustered together with strains from Colombia and Venezuela. The highest nucleotide similarities were shared between the Madeiran strain and a strain from Colombia from 2008 (99.9\%). The Madeiran strain had a single nucleotide synonymous substitution $(T \circledast C)$ in comparison to the Colombian strain at position 2,040 (GenBank accession number: GQ868570).

Additional sequences from the C-preM region [3] were also compared to Genbank sequences and to the available sequence of the autochthonous case from Madeira that became recently available [6]. The sequence from the first patient was identical to the sequence from the autochthonous case within the alignable region of 385 $\mathrm{bp}$, and the sequence from the second patient had a single nucleotide change (position 82, GenBank accession number: KC248375). The BLAST search results for the $C$-preM sequences were in line with those of the E-gene sequence, showing highest sequence homologies to strains from South America.

\section{Discussion and conclusion}

Our results are in line with previous reports $[1,5,6]$, and all data thus far suggests that possibly a single strain of DENV-1 likely originating from South America caused the Madeiran epidemic, although more sequence data, e.g. complete genome data and sequences from more patients of the outbreak would be needed to confirm these findings.

Interestingly, DENV-1 was also identified in 2010 from autochthonous cases in southern France [13] and in Croatia $[14,15]$. The available sequences from Croatia [15] did not represent the same region as our sequence, and thus could not be included in our analysis. The analysis of the sequences from Croatia was based on short E-NS1 junction sequences (222 bp). The results suggested that the Croatian DENV-1 also represented genotype III (a genotype also designated as American/ African genotype $V$ ), but grouped together with strains from India [15]. As the Croatian sequences were associated with strains from India rather than strains from South America, it seems unlikely that the Croatian strains would be closely related to the strain circulating in Madeira. However, more comprehensive sequence data would be needed from the autochthonous cases found previously in Europe for comparisons.

Aside from the autochthonous cases of dengue fever in southern France [13] and Croatia [14], the Madeiran event is the first epidemic of dengue fever in Europe since 1928 , when Greece was affected by an outbreak $[16,17]$. The 2012 Madeiran epidemic has had a great impact on local residents, but has also affected visitors of the island. The latest available data from February 2013 reports that 78 visitors from European countries got infected in Madeira [18]. These countries, listed according to decreasing number of cases, include the United Kingdom, Germany, mainland Portugal, Finland, Sweden, and France, followed by Denmark, Austria and Norway, and finally Croatia, Slovenia, Spain and Switzerland. The number of imported cases in Europe is however likely to be an underestimate. Also the actual number of persons in Finland, who got infected by DENV in Madeira may be higher than the number reported here as the travel history information was not available for all the suspect dengue patients whose samples were tested at the HUSLAB.

Whereas the risks for possible endemic transmission of dengue virus (DENV) in Europe have been mainly associated with the spreading of Stegomyia albopicta (=Aedes albopictus) [13,14], interestingly, the vector associated with the Madeiran outbreak was reported to be Stegomyia aegypti (=Aedes aegypti) [1] as was the 1928 outbreak in Greece [16,17] (mosquito nomenclature according to Reinert et al., 2009 [19]).

Similarly to Madeira, it has been suggested that island locations that are major tourist attractions such as Mauritius [20] may be at elevated risk for dengue introduction via travellers if suitable vectors are available. Although significant efforts have been taken to map and collect the information of the relevant mosquito vectors of mosquito-transmitted diseases in Europe 


\section{FIGURE}

Phylogenetic analysis of partial envelope gene sequence derived from two imported dengue cases from Madeira to Finland, 2012

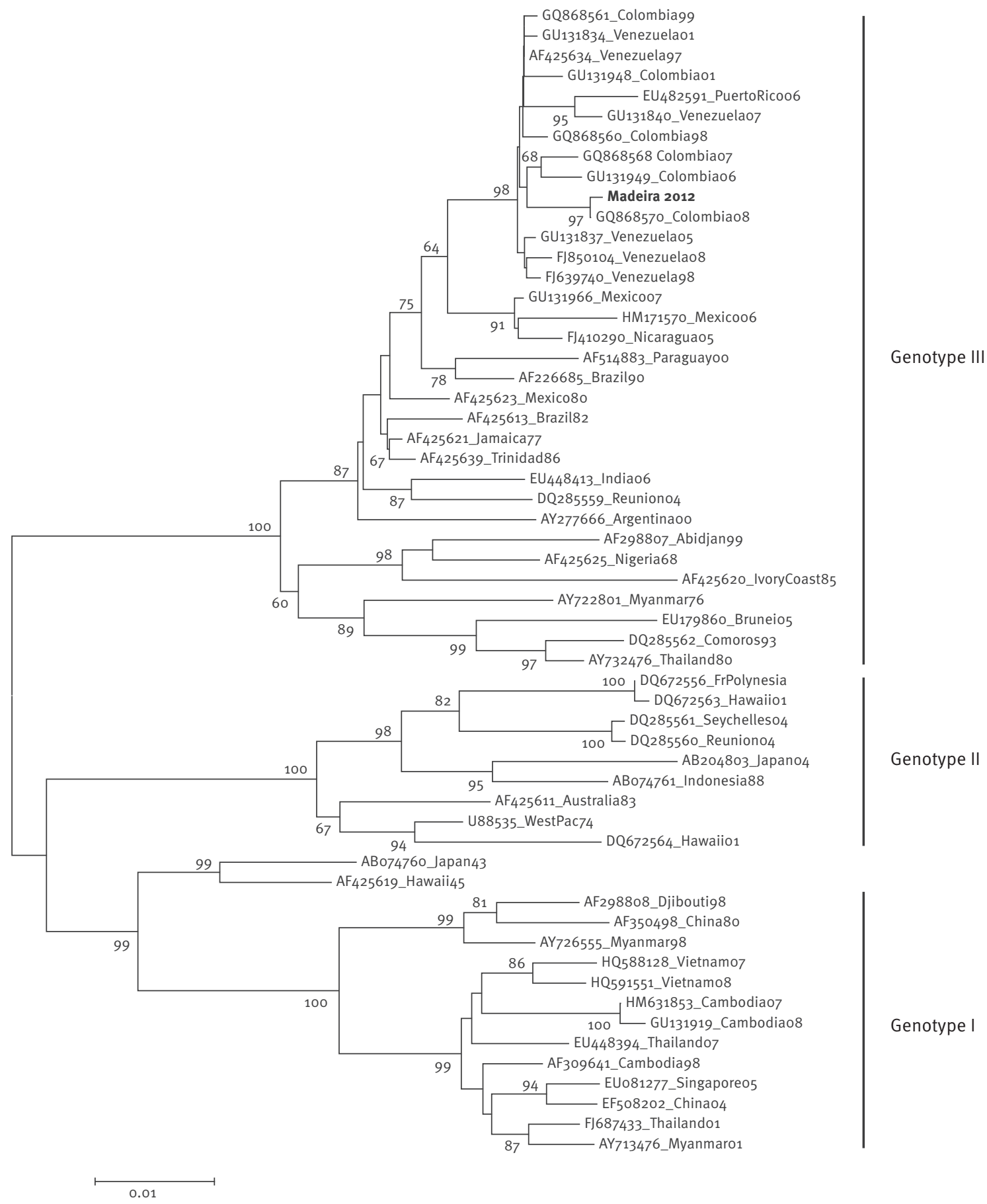

The tree, determined by neighbour-joining method, was based on partial ( $933 \mathrm{bp}$ ) envelope gene sequences of dengue viruses of serotype 1. Bootstrap support values $>60 \%$ are shown at the nodes. The scale bar represents nucleotide substitutions per site. The GenBank accession numbers of the sequences used as well as the country of origin and year are shown on the tree. The strain from the case imported from Madeira in 2012 is indicated in bold and clusters with strains of genotype III (a genotype also designated as American/African genotype V). 
by e.g. the European Centre for Disease Prevention and Control (ECDC) VBORNET, this information is not available from all locations. For example, according to ECDC VBORNET mosquito maps [21] no information is currently available on competent dengue vectors, (Stegomyia albopicta (=Aedes albopictus) or Stegomyia aegypti (=Aedes aegypti)) for some locations situated relatively closely to Madeira, such as the Canary Islands. The Madeiran outbreak highlights the importance for obtaining up-to-date information of the vector species distribution in Europe and urges the need for planning countermeasures and surveillance at virological, medical and environmental levels [22].

Although the Madeiran dengue outbreak was widely reported in the international news, dengue may still not be generally suspected in intra-European travellers. The possible endemisation of dengue in Europe highlights the need for diagnostic preparedness and awareness of clinicians to suspect and recognise dengue originating from within Europe. We conclude that the detailed molecular characterisation of the DENV strains from travellers, autochthonous cases and outbreaks are needed for studying the molecular epidemiology and transmission chains of dengue virus strains in Europe.

\section{Acknowledgements}

The authors thank Dr. Anssi Reponen and Dr. Timo Tuominen for providing patient information and HUSLAB for financial support.

\section{Conflict of interest}

None declared.

\section{Authors' contributions}

All authors contributed to the study design, interpretation of the results, writing of the manuscript and approved the final version. EMK performed RNA extractions and RT-PCR tests. $\mathrm{EH}$ performed the NS1 antigen tests, sequence analysis and wrote the first version of the manuscript. OV collected the diagnostic and clinical data.

\section{References}

1. Sousa CA, Clairouin M, Seixas G, Viveiros B, Novo MT, Silva AC, et al. Ongoing outbreak of dengue type 1 in the Autonomous Region of Madeira, Portugal: preliminary report. Euro Surveill. 2012;17(49):pii=20333. Available from: http:// www.eurosurveillance.org/ViewArticle.aspx?Articleld $=20333$ PMid:23231893

2. European Centre for Disease Prevention and Control (ECDC). Rapid Risk Assessment. Update on autochthonous dengue cases in Madeira, Portugal. Stockholm: ECDC; 20 Nov 2012. Available from: http://www.ecdc.europa.eu/en/publications/ Publications/Forms/ECDC_DispForm.aspx?ID=1003

3. Lanciotti RS, Calisher CH, Gubler DJ, Chang GJ, Vorndam AV. Rapid detection and typing of dengue viruses from clinical samples by using reverse transcriptase-polymerase chain reaction. J Clin Microbiol. 1992;30(3):545-51. PMid:1372617 PMCid:265106

4. Gaunt MW, Gould EA. Rapid subgroup identification of the flaviviruses using degenerate primer E-gene RTPCR and site specific restriction enzyme analysis. J Virol Methods. 2005;128(1-2):113-27.http://dx.doi.org/10.1016/j. jviromet.2005.04.006 PMid:15927275

5. National Institute of Health Dr. Ricardo Jorge. Febre de dengue na Madeira, Diagnóstico laboratorial. [Dengue fever in
Madeira. Laboratory diagnosis]. Lisbon: National Institute of Health Dr. Ricardo Jorge; 9 Oct 2012. Available from: http:// www.insa.pt/sites/INSA/Portugues/ComInf/Noticias/Paginas/ DengueMadeiraDiagLab.aspx

6. Alves MJ, Fernandes PL, Amaro F, Osório H, Luz T, Parreira $P$, et al. Clinical presentation and laboratory findings for the first autochthonous cases of dengue fever in Madeira island, Portugal, October 2012. Euro Surveill. 2013;18(6): pii=20398. Available from: http://www.eurosurveillance.org/ViewArticle. aspx?Articleld=20398 PMid:23410256

7. A-Nuegoonpipat A, Berlioz-Arthaud A, Chow V, Endy T, Lowry $\mathrm{K}$, Mai le $\mathrm{Q}$, et al. Sustained transmission of dengue virus type 1 in the Pacific due to repeated introductions of different Asian strains.Virology. 2004;329(2):505-12. http://dx.doi. org/10.1016/j.virol.2004.08.029 PMid:15518827

8. Schreiber MJ, Holmes EC, Ong SH, Soh HS, Liu W, Tanner L, et al. Genomic epidemiology of a dengue virus epidemic in urban Singapore. J Virol. 2009;83(9):4163-73. http://dx.doi. org/10.1128/JVI.02445-08 PMid:19211734 PMCid:2668455

9. Myat Thu H, Lowry K, Jiang L, Hlaing T, Holmes EC, Aaskov J. Lineage extinction and replacement in dengue type 1 virus populations are due to stochastic events rather than to natural selection. Virology. 2005;336(2):163-72. http://dx.doi. org/10.1016/j.virol.2005.03.018 PMid:15892958

10. Goncalvez AP, Escalante AA, Pujol FH, Ludert JE, Tovar D, Salas $R A$, et al. Diversity and evolution of the envelope gene of dengue virus type 1 . Virology. 2002;303(1):110-9. http://dx.doi. org/10.1006/viro.2002.1686 PMid:12482662

11. Rico-Hesse, R. Molecular evolution and distribution of dengue viruses type 1 and 2 in nature. Virology. 1990;174 (2):479-93. http://dx.doi.org/10.1016/0042-6822(90)90102-W

12. Weaver SC, Vasilakis N. Molecular evolution of dengue viruses: contributions of phylogenetics to understanding the history and epidemiology of the preeminent arboviral disease. Infect Genet Evol. 2009;9(4):523-40. http://dx.doi.org/10.1016/j. meegid.2009.02.003 PMid:19460319

13. La Ruche G, Souarès Y, Armengaud A, Peloux-Petiot F, Delaunay $P$, Desprès $P$, et al. First two autochthonous dengue virus infections in metropolitan France, September 2010. Euro Surveill. 2010;15(39):pii=19676. Available from: http:// www.eurosurveillance.org/ViewArticle.aspx?Articleld $=19676$ PMid:20929659

14. Gjenero-Margan I, Aleraj B, Krajcar D, Lesnikar V, Klobučar A, Pem-Novosel I, et al. Autochthonous dengue fever in Croatia, August-September 2010. Euro Surveill. 2011;16(9):pii=19805. Available from: http://www.eurosurveillance.org/ViewArticle. aspx?Articleld $=19805$

15. Kurolt IC, Betica-Radić L, Daković-Rode O, Franco L, Zelená $\mathrm{H}$, Tenorio A, et al. Molecular characterization of dengue virus 1 from autochthonous dengue fever cases in Croatia. Clin Microbiol Infect. 2012. http://dx.doi.org/10.1111/14690691.12104 PMid:23279586

16. Halstead SB, Papaevangelou G. Transmission of dengue 1 and 2 viruses in Greece in 1928. Am J Trop Med Hyg. 1980;29(4):635-7. PMid:6996504

17. Papaevangelou G, Halstead SB. Infections with two dengue viruses in Greece in the 2oth century. Did dengue hemorrhagic fever occur in the 1928 epidemic? J Trop Med Hyg. 1977;80(3):46-51. PMid:327086

18. European Centre for Disease Prevention and Control (ECDC). Epidemiological update: Outbreak of dengue in Madeira, Portugal. Stockholm: ECDC; 14 Feb 2013. Available from: http://www.ecdc.europa.eu/en/press/news/Lists/News/ECDC DispForm.aspx? List $=32 \mathrm{e} 43 \mathrm{ee} 8 \% 2 \mathrm{De} 230 \% 2 \mathrm{D} 4424 \% 2 \mathrm{Da} 783 \% 2$ D85742124029a\&ID $=845 \&$ RootFolder $=\% 2$ Fen $\% 2$ Fpress $\% 2$ Fne ws $\% 2$ FLists $\% 2$ FNews

19. Reinert JF, Harbach RE, Kitching IJ. Phylogeny and classification of tribe Aedini (Diptera: Culicidae). Zool J Linn Soc. 2009;157(4):700-94. http://dx.doi. org/10.1111/j.1096-3642.2009.00570.x

20. Ramchurn SK, Goorah SS. Letter to the editor: Ongoing outbreak of dengue type 1 in the Autonomous Region of Madeira, Portugal. Euro Surveill. 2013;18(2): pii=20351. Available from: http://www.eurosurveillance.org/ViewArticle. aspx?Articleld $=20351$

21. European Centre for Disease Prevention and Control (ECDC). VBORNET maps - Mosquitoes. Stockholm: ECDC. [Accessed 21 Feb 2013]. Available from: http://ecdc.europa.eu/en/activities/ diseaseprogrammes/emerging_and_vector_borne_diseases/ Pages/VBORNET_maps.aspx

22. Gould EA, Gallian P, De Lamballerie X, Charrel RN. First cases of autochthonous dengue fever and chikungunya fever in France: from bad dream to reality! Clin Microbiol Infect. 2010;16(12):1702-4. http://dx.doi.org/10.1111/j.14690691.2010.03386.x PMid:21040155 